\title{
What's So Positive About Positive Psychology and Looked After Children
}

\author{
Ze'ev Levita $^{1 *}$ and Liat Levita ${ }^{2}$ \\ ${ }^{1}$ Consultant Clinical Psychologist, Stoke St Milborough, England
}

${ }^{2}$ Department of Psychology, University of Sheffield, England

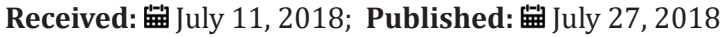

*Corresponding author: Ze'ev Levita, Consultant Clinical Psychologist, Positive Clinical Psychology Ltd, 9 Stoke Gorse, Stoke St Milborough, Shropshire

\begin{abstract}
The work with Looked after Children appears to be focused mainly on their past difficult life experiences. This article is trying to address this over-simplification and reflect on the implications regarding therapy.
\end{abstract}

\section{Introduction}

The concept of looked after children was introduced by Department of Health within the Children Act 1989. It describes all children in public care; i.e. children in foster and residential care and children that live with their parents but are subject to care orders. It is estimated that more than 5 children and young people per 1000 under 18 years of age in England are looked after (Department of Health, 2001a; DCFS, 2009). There are indications that these numbers are increasing (Department of Education, 2010) Some evidence (McCann et al. [1]; Scott [2]; Utting et al. [3]) indicates that $56 \%$ of looked after children have significant psychological difficulties and that $45 \%$ of looked after children present difficulties that can be recognised as mental health (psychiatric) disorder. This is more than four times the number that would be expected in the general population. However $44 \%$ of looked after children do not present significant psychological problems and 55\% do not present a psychiatric disorder. This more positive statistic is impressive but rather ignored one in the context of the difficult and traumatic developmental background of these children.

\section{Why Are Children Looked After?}

Looked after Children are in care because their parents are not available or not able to care for them. However the complete picture regarding their pre-natal, post-natal and childhood experiences is not always fully understood by the general public and regrettably sometimes by the professionals. Whilst the sensational and shocking facts of the most extreme cases, often involving physical and sexual abuse or extreme neglect, reach the public arena through the media, there appears to be less awareness of emotional neglect and the subtler psychological and physical deprivations that may have a dramatic effect on children's physical, emotional, cognitive and social development. In particular there is lack of awareness of the pre-natal and post-natal factors (Linnet et al. [4]; Szyf et al, [5]). Those include genetic factors, influences on both the health of the mother and her foetus during pregnancy and the physical and care environment after birth (Evans [6]; KimCohen, et al. [7]). In addition people's choice of partners may not be completely random (Rushton et al. [8]; Rushton \& Nicholson [9]). Indeed in animals it has been shown that epigenetic factors can influence choice of partners (Crews et al. [10]). Propensity for genetic disorders in certain populations may be higher than in other populations (Dohrenwend et al. [11]). In some populations pregnant mothers are more exposed to drugs, alcohol, poor diet, violence; etc (Anderson [12]; Williams \& Collins [13]). Many babies are born into environments that are unsafe, unhygienic, unhealthy, neglectful, inconsistent, threatening; parents may lack sufficient parenting skills and be mentally challenged (Belsky et al. [14])

\section{The Sad Story}

The past of a looked after child could be described as a sad story however there is more to the sad story than meets the eye. This story of difficult and tragic childhood experiences started to be written before it began to fully unfold, determined by the genetic and prenatal factors already mentioned (Gluckman \& Hanson [15]). What chance do these children have with this kind of genetic and experiential background? It would be reasonable to assume that they are all doomed to life of dysfunction, dependence and misery. 
However many of them defy this expectation. We are still in the process of learning about the protective and other factors that make the difference (Cocker \& Scott [16]; Masten \& Obradovic [17]; Murowchick [18]). For example, the quality of relationships with foster caregivers appears to be a very important factor in children's' abilities to regulate emotions and cope with stress and challenges. (Oosterman et al. [19]).

The more we learn the more we are inclined to think that some people become positive, successful and well functioning not in spite of their difficult background and experiences but because of them.

From Repairing the Sad Story to Building on the Sad Story

The sad story has already been written. It belongs to the past and the past cannot be changed. We live always in present and any moment in life defines its present. It is those moments of 'present', the 'here and now' that provide us with the opportunity for change Bishop et al. [20] It is important to have the opportunity to change our stance towards the past and changing our plans for the future. This of course depends very much on whether we are willing and able to take this pro-active stance. If not, we are at the mercy of our sad story and this will dictate to large extend what we think, feel and do (Langle \& Sykes [21]). Many of the children who are looked after, regrettably, are either not aware or not able or both, to take a stance towards their past. What is even more tragic is that many professionals are the same in this sense. There appears to be a shared and mutually reinforcing approach that the past explains and is responsible fully for, what happens now and how it defines the future. This approach is very much reinforced by a deterministic view of psychology and behaviour; e.g. Freud (Wallwork [22]) and from the other side of the theoretical spectrum: Skinner (Skinner [23]).

Humanistic Psychology provides us with the opportunity to view the person from a non-pathologising perspective (Clay, 2002). Rollo May and Carl Rogers emphasise the human ability to make choices and self-direct their behaviour. The Existential Psychology approach focuses on the way people deal with the givens of their existence and what there are (Yalom, 1980). Victor Frankl for example promotes people ability to create meaning as a way to cope with uncontrollable and un-avoidable facts of existence (Frankl, 1997). In this way both Humanism and Existentialism created a picture of a human being as able and even responsible for determination of their stance and behaviour. In more than one sense Humanistic and Existential Psychology could be seen as forerunners of Positive Psychology movement. It appears that these approaches have not yet made significant enough impact on work and intervention with Looked after Children.

\section{From Repairing the Worst Things in Life to Building the Best Qualities in Life}

Most (but not all) of therapeutic work with looked after children tends to focus on the factors that have detrimental effect on the client's wellbeing and behaviour. There appears to be an emphasis on 'repair'. If only, through interaction with the client (discussion, play, rapport and interpersonal relationship), we would 'fix' those destructive and detrimental factors than we would help the client on his/her road to recovery. There are at least four big questions related to this kind of approach: Is it actually possible? (Can we as yet manipulate the hereditary factors; can we change what has already happened in the past)? Even if it is possible, do we not face the danger of destroying those hereditary 'negative' and experientially painful elements that have the potential to promote personal uniqueness, specific talents, creativity, excellence, achievement motivation; etc. (Levita [24]) Do we, by focusing on the factors that make us unhealthy, dysfunctional, unhappy; etc. unintentionally promote the clients' sense of vulnerability and helplessness, as well as our perception of the clients' vulnerability and helplessness? Do we, through the focus on the past and the time spent in therapy prevent exposure to, and potential positive effects of, present experiences? The Positive Psychology approach shifts the emphasis from fixing what makes us unhealthy to exploration and utilisation of factors that make us healthy (Seligman \& Csikszentmihalyi [25]), providing a guiding light to possible change in the emphasis of therapeutic work and intervention with children who are looked after (Houston [26]; Kalke, Glanton, \& Cristalli [27]; Snyder and Lopez [28]; Linley and Joseph [29]; Joseph and Linley [30]).

More recent articles argue for the integration of Clinical psychology and Positive Psychology; e.g. (Johnson and Wood [31]) and provide evidence of the efficacy of using Positive Psychology intervention methods; e.g. (Chavez et al [32]; Roth, Suldo \& Ferron [33]). The concept of Therapy for Looked after Children itself is challenged if we are to be open to the ideas from positive psychology. Promotion of scholastic achievement is one such concept. Provision of daily experiences that promote happiness and wellbeing; training for work and vocation; promoting civility, kindness and altruism; supporting special talents, are only some of the other challenging ideas [34]. Other ideas are not necessarily alien to Therapy but provide shift of emphasis; e.g. promoting resilience, self efficacy and optimism as well as helping to develop positive personal traits; e.g. courage and interpersonal skills [35]. And finally a concept that in the spirit of this paper may be the most important: promoting the functional aspects of personal uniqueness

\section{Conclusion}

The intention of this paper is not necessarily to overthrow the traditional approaches to therapy but to reflect on a radically different way of thinking about therapy aims and methods [35]. Neglecting completely the traditional methods would not sit easy with the conceptual framework of positive psychology that would, by and large, promote diversity of thought and ideas [36]. However, it challenges the idea that the sad story produces a broken child that we need to fix; rather it suggests that the past, however traumatic, and the genetic load, however specific, contribute to our own uniqueness and diversity of being and that by focusing 
on that which is healthy, the therapeutic process can facilitate the individual child in finding their own pathway to a more positive future [37].

\section{References}

1. McCann JB, James A, Wilson S, Dunn G (1996) Prevalence of psychiatric disorders in young people in the care system. BMJ 313(7071): 15291530.

2. Scott S (2004) Reviewing the research on the mental health of looked after children: Some issues for the development of more evidence informed practice. International Journal of Child and Family Welfare 7(2-3): 86-97.

3. Utting W, Baines C, Stuart M, et al (1997) People Like Us: The Report of the Review of the Safeguards for Children Living Away from Home. London: The Stationery Office.

4. Linnet KM, Dalsgaard S, Obel C, Wisborg K, Henriksen TB, et al. (2003) Maternal Lifestyle Factors in Pregnancy Risk of Attention Deficit Hyperactivity Disorder and Associated Behaviours: Review of the Current Evidence. Am J Psychiatry 160(6): 1028-1040.

5. Szyf M, McGowan P, Meaney MJ (2008) The social environment and the epigenome. Environmental and Molecular Mutagenesis 49(1): 46-60.

6. Evans GW (2006) Child development and the physical environment. Annu Rev Psychol 57: 423-451.

7. Kim Cohen J, Caspi A, Taylor A, Williams B, Newcombe R, et al. (2006) MAOA, maltreatment, and gene-environment interaction predicting children's mental health: new evidence and a meta-analysis. Mol Psychiatry 11(10): 903-913.

8. Rushton JP, Littlefield CH, Lumsden CJ (1986) Gene-culture coevolution of complex social behaviour: human altruism and mate choice. Proceedings of the National Academy of Sciences 83(19): 7340-7343.

9. Rushton JP, Nicholson IR (1988) Genetic similarity theory, intelligence, and human mate choice. Ethology and Sociobiology 9(1): 45-58.

10. Crews D, Gore AC, Hsu TS, Dangleben NL, Spinetta M, et al. (2007) Transgenerational epigenetic imprints on mate preference. Proceedings of the National Academy of Sciences 104(14): 5942-5946.

11. Dohrenwend B, Levav I, Shrout P, Schwartz S, Naveh G, et al. (1992) Socioeconomic status and psychiatric disorders: the causation-selection issue. Science 255(5047): 946-952.

12. Anderson AS (2007) Nutrition interventions in women in low-income groups in the UK. Proceedings of the Nutrition Society 66(1): 25-32.

13. Williams DR, Collins C (1995) US Socioeconomic and Racial-Differences in Health, Patterns and Explanations. Annual Review of Sociology 21: 349-386.

14. Belsky J, Bell B, Bradley RH, Stallard N, Stewart-Brown SL (2007) Socioeconomic risk, parenting during the preschool years and child health age 6 years. The European Journal of Public Health 17(5): 508513.

15. Gluckman PD, Hanson MA (2004) Living with the Past: Evolution, Development, and Patterns of Disease. Science 305(5691): 1733-1736.

16. Cocker C, Scott $S$ (2006) Improving the mental and emotional well-being of looked after children: connecting research, policy and practice. The Journal of the Royal Society for the Promotion of Health 126(1): 18-23.

17. Masten AS, Obradovic J (2006) Competence and resilience in development. Resilience in Children 1094: 13-27.
18. Murowchick E (2002) Resilience and development: Positive life adaptations. Family Relations 51(2): 186-187.

19. Oosterman M, de Schipper JC, Fisher P, Dozier M, Schuengel C (2010) Autonomic reactivity in relation to attachment and early adversity among foster children. Development and Psychopathology 22(1): 109118.

20. Bishop SR, Lau M, Shapiro S, Carlson L, Anderson ND, et al. (2004) Mindfulness: A Proposed Operational Definition. Clinical Psychology: Science and Practice 11(3): 230-241.

21. Langle A, Sykes BM (2006) Viktor Frankl, Advocate for Humanity: On his 100th Birthday. Journal of Humanistic Psychology 46(1): 36-47.

22. Wallword, Ernest (1991) Psychoanalysis and Ethics London: Yale University Press, USA.

23. Skinner B (1987) Whatever Happened to Psychology as the Science of Behaviour? American Psychologist 42(8): 780-786.

24. Levita Z (2008) Accomplishment Through Autism and Judo, Clinical Psychology.

25. Seligman MEP, Csikszentmihalyi M (2000) Positive psychology. An introduction. American Psychologist 55(1): 5-14.

26. Houston S (2006) Making use of Positive Psychology in Residential Child Care. In I. Iwaniec The Child's Journey through Care: Placement stability, care-planning, and achieving permanency pp. 183-199.

27. Kalke T, Glanton A, Cristalli M (2007) Positive behavioural interventions and supports: using strength-based approaches to enhance the culture of care in residential and day treatment education environments. Child Welfare 86(5): 151-174.

28. Snyder SR, Lopez J (2005) Handbook of Positive Psychology Oxford (Eds.) University Press.

29. Linley PA, Joseph S (2004) (Eds) Positive Psychology in Practice. Wiley.

30. Joseph S, Linley PA (2006) Positive Therapy; A meta-theory for positive psychology practice London and New York Routledge.

31. Johnson Judith, Wood Alex M (2017) Integrating Positive and Clinical Psychology: Viewing Human Functioning as Continua from Positive to negative Cam benefit Clinical assessment, Interventions and Understanding of Resilience. Cognitive Therapy and Research 41(3): pp.335-349.

32. Chavez C, Lopez Gomez I, Hervaz G, Vazqueze C (2017) A Comparative Study on the Efficacy of a Positive Psychology Intervention and Cognitive Behavioural Therapy for Clinical Depression. Cognitive Therapy and Research 41(3): 417-433.

33. Roth Rachel, Suldo Shannon M, Ferron John M (2017) Improving Middle School Students' Subjective Well Being: Efficacy of a Multicomponent Positive Psychology Intervention Targeting Small Groups of Youth. School Psychology Review 46(1): 21-41.

34. PL Bennett (1989) Department of Health. An introduction to the Children Act 1989. London: HMSO.

35. (2001) Department of Health. Children Looked After in England: 2000/2001 (Bulletin 2001/26). London: Department of Health.

36. Department of Education (2010) Children looked after in England (including adoption and care leavers) year ending 31 March 2010, Department of Education, London.

37. (2009) Department for Children, Schools and Families (DCSF) Children looked after in England (including adoptions and care leavers) London: DCSF. 
(C) This work is licensed under Creative

To Submit Your Article Click Here : Submit Article

DOI: 10.32474/RRHOAJ.2018.02.000140

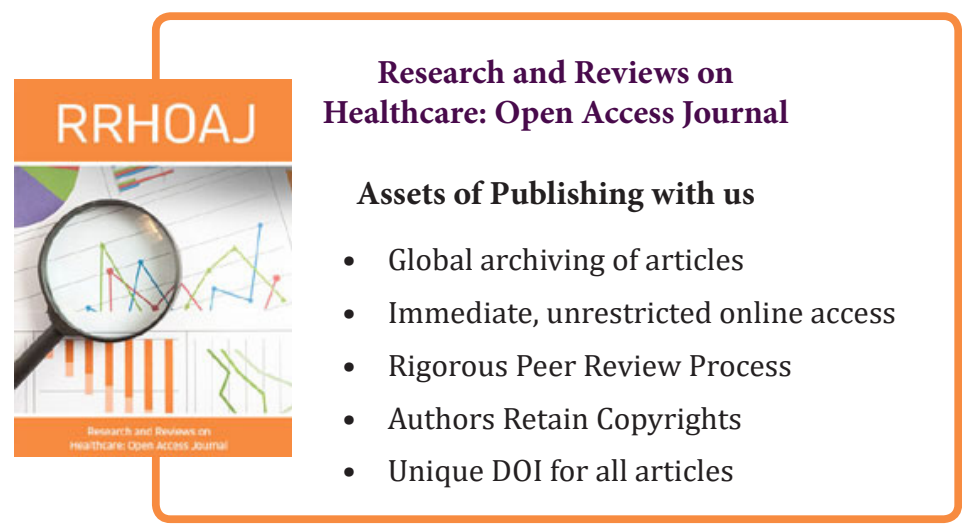

